12th.- - Yesterday, an enema acted copiously; to-day, the bowels were naturally moved; pulse 100 ; wound very healthy.

I need not continue the record any further. She rapidly improved, and on the fourteenth day the wound had healed, and she was ready to leave her bed.

Remarks.-This was, I think, a case upon which the most sanguine surgeon would have pronounced an unfayourable prognosis; and taking into consideration that the strangulation had existed four days-that she was a weakly woman, debilitated by previous illness-that the entrapped intestine was congested to lividity and incipient gangrene-and that the peritoneal membrane had begun to sympathize with the gut, I believe most justly so. But, the operation over, all morbid processes ceased, and the vis medicatrix naturce fully proved the wisdom of our attempt. That the pulse never rose above 112 , that no sloughing worthy of mention followed, that the imprisoned bowel so soon recovered its natural function, and that the constitutional symptoms after the operation were so insignificant, are all, in my opinion, facts worthy of note, and full of encouragement for the future. I am convinced that long-attempted taxis, where strangulation is not recent, is as useless as it is perilous, and that if it succeeds once, it fails twenty times. I feel sure, too, in these days, a generons diet and due administration of stimulants after an operation often ward off extensive suppuration and vital depression; or, failing that, enable the patient to survive them.

Gresford Cottage, 1859 .

\section{EXTENSIVE CARIES OF THE OS CALCIS CURED BY OPERATION.}

BY WILLIAM STILLMAN, M.D., Southam.

$\mathrm{MR}_{\mathrm{R}} \mathrm{S}-$, aged twenty-eight, looking pale and cachectic, came under my care some time ago. He was then suffering from cough and night-sweats. Upon examination, I found the upper portion of the left lung in the first stage of tubercular disease. Under a course of treatment, with tonics and codliver oil, he much improved, and almost lost his cough. Becoming moderately stout and healthy-looking, my attendance then ceased until five months ago, when I was again summoned in consequence of the patient having met with an accident, by which his left ankle was sprained and the heel bruised. The redness and swelling of the ankle subsided under treatment; but the outer side of the heel continued much inflamed, and there was deep-seated pain upon pressure. Leeches were applied without benefit, and after three weeks had elapsed from the time of the accident I detected fluid, which I evacuated; the finid was thin and unhealthy-looking. In a short time it again formed, and discharged itself by means of two sinuses; a probe passed through either of these openings readily detected diseased bone. As the patient was again suffering from cough and expectoration, with night-sweats, I placed him under constitutional treatment, giving him quinine and cod-liver oil, with iodide of iron. His sweats and expectoration left him; a slight cough in the morning only remained; but the local disease was evidently extending, and, fearing that other bones of the foot would become implicated unless the disease was removed, I determined to operate without delay, and did so on July 12th, 1858. I made a crucial incision on the outer side of the os calcis below the malleolus externus and slightly behind it and removed with the gouge nearly the whole of the cancellated portion of the bone, the disease being so extensive as to necessitate this. There was very little blood lost. In consequence of the thoracic disease I did not use chloroform.

Since the operation the foot has gone on well under simple water dressing, and upon examination on August 9th, I found the wound quite healed, and the foot free from either swelling or pain. The patient has continued to take the oil, and will do so for some time. The lung disease is arrested, and may with care on the part of the patient continue so for years.

The case most certainly points out the necessity for not deferring operative measures in caries after the disease has once become confirmed and shows a tendency to extend; for I have no hesitation in saying that, had I not removed the disease when I did, the neighbouring bones wonld have become carious, and there would most likely have been an end to any conservative measure, besides the probability that the sufferer would have died from the exhaustion and constitutional irritation produced. As it is, he has a healthy foot, and, should he be spared, the cavity will again become filled by bone. Of course it will be some time before the heel is strong enough to bear any weight.

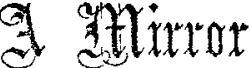

OF THE PRACTICE OF

\section{MEDICINE AND SURGERY IN THE}

\section{HOSPITALS OF LONDON.}

Nulla est alia pro certo noscendi via, nisi quam plurimas et morborum et dissectionum historias, tam aliornm proprias, collectas habere et inter se comparare.-MorgagNI. De Sed. et Caus. Morb., lib. 14. Procmium.

\section{WESTMINSTER HOSPITAL}

\section{COMPOUND COMMINUTED FRACTURE OF THE LEG, FOL-} LOWED BY GANGRENE.

AMPUTATION AT THE KNEE-JOINT BY RECTANGULAR FLAPS; FATAL RESULT.

(Under the care of Mr. HoLTHodse.)

WELL-DIRECTED conservative efforts will do much to save both life and limb in the great majority of severe injuries. In the following case, however, wherein there was not only hæmorrhage from a torn artery, but also the formation of large bullæ a few hours after the accident, we think an earlier resort to amputation would have held out a better chance for the life of the patient, whose occupation was of a well-known unhealthy character-namely, that of a brewer's drayman. Mortification commenced at an early period, and produced a fatal result, from exhaustion, two days after the operation, and thirteen days from the receipt of the injury.

There is a young man at the present time in the Royal Free Hospital, under Mr. T. Wakley's care, who sustained a compound fracture not unlike that in Mr. Holthouse's patient. It was determined to resort to amputation, but as no bloodvessel was wounded, and the patient's age and constitutional powers were favourable, the limb was put up in a Macintyre's splint, and a recovery has ensued, with an excellent limb. We hope shortly to record this very interesting case.

For the following notes we are indebted to Mr. Ponsonby Kelly Adair, house-surgeon to the hospital :-

Henry $\mathrm{H}-1$, aged sixty, was admitted into Henry Hoare ward on the 14th of December, 1858, with a compound fracture of the left leg. He is a brewer's drayman, and whilst at work fell down into a cellar. When brought to the hospital about four P.M., it was found that both the tibia and fibula of the left leg were broken, and that the fracture of the tibia was both compound and comminuted, two of the pieces protruding through an opening in the skin, just over the upper part of the lower third of the leg. These were removed, and the wound covered with a piece of lint soaked in blood so as completely to exclude the air. There was at this time but little hæmorrhage, which was venous. The limb was placed in position on a Macintyre's splint, well padded, and an evaporating lotion applied to the injured part. The man had a most unhealthy look, and fears were expressed as to the ultimate issue of the case. During the evening, in spite of the closure of the wound, a small stream of blood tlowed from it at intervals, and large bullæ formed about the seat of the fracture.

During the two or three succeeding days, the bleeding occasionally recurred, and the leg swelled very much. Above the wound there was a sense of fluctuation, as though blood or some other fluid were under the muscles. There was also a good deal of cedematous pitting on pressure, and when a grooved needle was introduced pretty deeply on the outer side of the leg, a few inches above the wound, where the fluctuation was felt, a small quantity of blood and thin serum oozed out. Very large bullæ, filled with blood and serum, formed about the wound, and also behind it, and bursting, left the whole of the leg at the seat of the injury raw.

Dec. 2lst. - The bowels have been moved for the first time 387 